Wahyudin, A. · D. Widayat · T. Nurmala · F. Y. Wicaksono · A.W. Irwan · A. Hafiz

\title{
Respons tanaman jagung (Zea mays L.) hibrida terhadap aplikasi paraquat pada lahan tanpa olah tanah (TOT)
}

\author{
Response of hybrids maize (Zea mays L.) due to application of \\ paraquat at zero tillage
}

Diterima : 15 Oktober 2018/Disetujui : 18 Desember 2018 / Dipublikasikan : 31 Desember 2018

CDepartment of Crop Science, Padjadjaran University

\begin{abstract}
This study aims to determine growth and yield of maize caused by land preparation using paraquat herbicide at zero tillage, then find the best dosage of paraquat that can be replaced full tillage in maize cultivation. The experiment was conducted at the experimental field Ciparanje, Faculty of Agriculture, University of Padjadjaran, Jatinangor, Sumedang Regency, West Java at \pm 750 meters above sea level, soil order was Inceptisols, the type of rainfall was C3 according Oldemann classification. The experiment conducted from May 2017 until August 2017. It used randomized block design that consisted of 6 treatments and repeated four times. The treatments were: zero tillage + Paraquat Dicloride at the dosage $207 \mathrm{~g} / \mathrm{L}$, zero tillage + Paraquat Dicloride at the dosage $276 \mathrm{~g} / \mathrm{L}$, zero tillage + Paraquat Dicloride at the dosage $345 \mathrm{~g} / \mathrm{L}$, zero tillage + Paraquat Dicloride at the dosage $414 \mathrm{~g} / \mathrm{L}$, zero tillage + weeding manual, and full tillage as control. The results of the experiments showed that application of paraquat $414 \mathrm{~g} / \mathrm{L}$ can replace full tillage.
\end{abstract}

Keywords : Land preparation - Paraquat - Maize - Zero tillage

Sari. Penelitian ini bertujuan untuk mempelajari pertumbuhan dan hasil tanaman jagung akibat persiapan lahan dengan menggunakan herbisida paraquat pada lahan tanpa olah tanah (TOT), serta memperoleh dosis yang tepat yang dapat digunakan dalam budidaya jagung untuk menggantikan olah tanah sempurna (OTS). Percobaan dilaksanakan di Kebun Percobaan

\footnotetext{
Dikomunikasikan oleh Santi Rosniawaty

Wahyudin, A. $^{1} \cdot$ D. Widayat ${ }^{1}$. T. Nurmala ${ }^{1}$. F. Y.

Wicaksono ${ }^{1}$ A.W. Irwan ${ }^{1}$ - A. Hafiz ${ }^{2}$

1 Staf pengajar Fakultas Pertanian Unpad

2 Alumni Fakultas Pertanian Unpad

Korespondensi: agus.wahyudin@unpad.ac.id
}

Ciparanje Fakultas Pertanian Universitas Padjajaran, Jatinangor, Kabupaten Sumedang, Jawa Barat dengan ketinggian tempat \pm 750 meter diatas permukaan laut dan ordo tanah Inceptisol serta tipe curah hujan C3 menurut Oldeman (1975). Percobaan dilaksanakan dari bulan Mei 2017 hingga Agustus 2017. Metode percobaan yang digunakan adalah Rancangan Acak Kelompok terdiri dari 6 perlakuan dan diulang sebanyak 4 kali. Perlakuannya adalah sebagai berikut : Perlakuan TOT + Herbisida Paraquat Diklorida Dosis 207g/L, TOT + Herbisida Paraquat Diklorida Dosis 276g/L, TOT + Herbisida Paraquat Diklorida Dosis 345g/L, TOT + Herbisida Paraquat Diklorida Dosis 414g/L, TOT + Penyiangan Manual, dan Kontrol (OTS). Hasil percobaan menunjukkan bahwa pemberian herbisida paraquat $414 \mathrm{~g} / \mathrm{L}$ untuk persiapan lahan dengan TOT pada tanaman jagung dapat menyamai OTS.

Kata kunci : Paraquat · Persiapan lahan · Jagung - Tanpa olah tanah

\section{Pendahuluan}

Tanaman Jagung (Zea mays L.) merupakan salah satu komoditas pangan penting bagi Indonesia setelah padi. Jagung memiliki peranan strategis dan bernilai ekonomis serta mempunyai peluang untuk dikembangkan, mengingat komoditas ini mempunyai fungsi yang multiguna, selain berperan sebagai bahan makanan pokok pengganti beras juga sebagai pakan ternak dan industri. Dewasa ini penggunaan jagung untuk kebutuhan bahan baku industri mulai berkembang, seperti pembuatan minyak jagung, tepung, pati, serta industri kimia (etil alkohol aseton, asam laktat, asam sitrat dan gliserol) (Purwono dan Hartono, 2005). 
Ketersediaan jagung di pasar dunia saat ini semakin terbatas karena tingginya permintaan dari negara importir. Oleh karena itu, upaya peningkatan produksi jagung di dalam negeri perlu ditingkatkan (Gratio, 2013). Berdasarkan data BPS tahun 2013-2015 produksi jagung mengalami penurunan, produksi jagung di Jawa Barat pada tahun 2013 sebesar 1.101 .998 ton, tahun 2014 sebesar 1.047.077 ton dan tahun 2015 sebesar 959.933 ton (BPS, 2015). Untuk itu, produksi jagung harus ditingkatkan.

Salah satu upaya untuk meningkatkan produksi jagung adalah dengan melakukan kegiatan budidaya yang efektif dan efisien. Persiapan lahan merupakan tahap awal dalam budidaya dan sangat penting diperhatikan dalam menunjang pertumbuhan tanaman. Persiapan lahan dilakukan untuk menciptakan kondisi yang mendukung bagi perkecambahan benih dan perkembangan akar tanaman serta mengurangi kompetisi terhadap gulma (Purwono dan Hartono, 2005).

Teknik persiapan lahan dalam praktiknya dikelompokkan ke dalam sistem olah tanah sempurna (OTS), olah tanah minimum (OTM), dan tanpa olah tanah (TOT). Sistem olah tanah sempurna merupakan cara yang umum diterapkan oleh petani dalam kegiatan persiapan lahan. Pengolahan tanah sempurna dimaksudkan agar tanah lebih gembur sehingga aerasi meningkat dan menghilangkan gulma di areal budidaya. Namun, pengolahan tanah yang intensif akan menyebabkan degradasi lahan yang menyebabkan daya dukung dan produktivitas lahan sesemakin menurun (Syam'um, 2002).

Sistem TOT merupakan bagian dari olah tanah konservasi (OTK) yang dikombinasikan dengan herbisida pada dosis yang tepat untuk mengendalikan gulma awal. Penerapan sistem TOT dengan herbisida bertujuan untuk menyiapkan lahan agar tanaman dapat tumbuh dan berproduksi dengan baik dengan memperhatikan keseimbangan ekologi lingkungan terutama air dan tanah.

Sisa gulma yang mati sebelumnya dapat menjadi mulsa yang berfungsi menambah bahan organik dalam tanah, menekan pertumbuhan kembali gulma dan meningkatkan tersedianya air tanah serta mengurangi dampak buruk tetesan air hujan (Moenandir, 2010). Selain itu, jumlah tenaga kerja yang dibutuhkan TOT lebih efisien sebesar 25,5\% dibanding sistem olah tanah maksimum (Rina dan Simatupang 1998).
Permasalahan yang dihadapi pada penggunaan sistem TOT adalah dalam mengendalikan gulma pada persiapan lahan, ketersediaan tenega kerja, biaya dan luasnya pertanaman. Keberadaan gulma pada areal produksi pertanian dapat menimbulkan kerugian hasil baik secara kualitas maupun kuantitas. Penurunan hasil tanaman akibat keberadaan gulma disebabkan oleh adanya kompetisi antara gulma dan tanaman dalam memperoleh air, cahaya, unsur hara dan ruang tumbuh serta berpotensi menjadi inang bagi hama dan penyakit tanaman (Tjitrosoedirdjo, dkk. 1984).

Pada areal yang luas dan tenaga kerja relatif mahal, penggunaan herbisida merupakan cara yang efektif dan efisien. Herbisida juga dapat mengurangi biaya produksi dalam sistem usahatani akibat upah tenaga kerja dalam penyiangan gulma yang relatif mahal, sehingga menguntungkan petani (Perkasa, 2015). Herbisida yang dapat digunakan antara lain yang berbahan aktif paraquat diklorida.

Paraquat diklorida adalah herbisida yang bersifat kontak dan tidak dapat diserap oleh bagian tanaman yang tidak hijau seperti batang dan akar serta tidak aktif di tanah. Penetrasi paraquat terjadi melalui daun. Keefektifan pemberian herbisida ditentukan oleh penggunaan dosisnya. Dosis herbisida yang tepat dapat mematikan gulma sasaran, tetapi jika dosisnya terlalu tinggi akan merusak tanaman budidaya (Sembodo, 2010).

\section{Bahan dan Metode}

Percobaan dilakukan di kebun percobaan Ciparanje Fakultas Pertanian Universitas Padjajaran, Jatinangor, Kabupaten Sumedang, Jawa Barat dengan ketinggian tempat \pm 750 meter diatas permukaan laut (dpl) dan ordo tanah Inceptisol serta tipe curah hujan C3 menurut Oldeman (1975). Percobaan dilaksanakan dari bulan Mei 2017 hingga Agustus 2017.

Bahan yang digunakan pada percobaan ini adalah benih jagung hibrida Bisi- 2, pupuk Urea, SP-36, $\mathrm{KCl}$, dan herbisida paraquat diklorida. Alat yang digunakan adalah sprayer knapsack semi automatic dan nozel T-jet, gelas ukur, oven, timbangan, tali rafia, meteran, papan perlakuan, kamera, alat tulis, Leaf area meter, dan cangkul.

Rancangan percobaan yang dilakukan adalah Rancangan Acak Kelompok (RAK). 
Banyaknya perlakuan adalah 6 perlakuan, yang diulang sebanyak 4 kali. Sehingga diperoleh 24 satuan percobaan. Berikut macam perlakuannya: A: TOT + herbisida Paraquat Diklorida Dosis 207g/L, B: TOT + herbisida Paraquat Diklorida Dosis 276g/L, C: TOT + herbisida Paraquat Diklorida Dosis 345g/L, D: TOT + herbisida Paraquat Diklorida Dosis 414g/L, E: TOT + penyiangan manual ( Satu kali penyiangan ), F: kontrol (OTS).

Pengolahan lahan dilakukan 1 minggu sebelum tanam. Persiapan lahan dilakukan sesuai dengan perlakuan. Pada perlakuan tanpa olah tanah (TOT), tanah dibiarkan tidak terganggu. Sebelum tanam, gulma dikendalikan dengan herbisida dengan dosis yang sesuai perlakuan.

Parameter pengamatan yang diamati adalah tinggi tanaman, indeks luas daun (ILD), panjang tongkol dan diameter tongkol, jumlah baris biji per tongkol, bobot 100 biji, bobot biji pipilan per tanaman, dan bobot biji pipilan per hektar.

\section{Hasil dan Pembahasan}

Tinggi Tanaman. Tinggi tanaman yang diukur pada 2, 4 dan 6 minggu setelah tanam (MST) ditampilkan pada Tabel 1. Berdasarkan Tabel 1, tinggi tanaman jagung pada 2, 4, dan 6 MST menunjukan pengaruh yang tidak berbeda nyata. Hasil analisis menunjukkan bahwa gulma yang telah dikendalikan masih mampu berkompetisi dengan tanaman jagung.

Tabel 1. Pengaruh pemberian herbisida paraquat pada tinggi tanaman jagung 2 MST, 4 MST, dan 6 MST (cm).

\begin{tabular}{cccc}
\hline Perlakuan & 2 MST & 4MST & 6 MST \\
\hline A & $25.10 a$ & $67.94 a$ & $91.69 a$ \\
B & $25.78 a$ & $66.83 a$ & $90.96 a$ \\
C & $22.89 a$ & $60.56 a$ & $83.84 a$ \\
D & $26.79 a$ & $69.11 a$ & $92.36 a$ \\
E & $22.49 a$ & $66.49 a$ & $82.48 a$ \\
F & $27.51 a$ & $72.71 a$ & $95.31 a$ \\
\hline
\end{tabular}

Keterangan: nilai rata-rata yang diikuti huruf yang sama pada kolom yang sama menunjukkan tidak berbeda nyata menurut uji Duncan pada taraf $5 \%$.

Gulma yang dapat berkembang biak dengan umbi, rimpang atau tunas dari bukubukunya dapat tumbuh subur kembali meskipun telah diaplikasikan herbisida paraquat. Persaingan dari gulma tersebut memberikan pengaruh negatif terhadap pertumbuhan jagung.

Pertumbuhan tinggi tanaman jagung yang kurang baik disebabkan oleh curah hujan yang sangat rendah, gulma yang mempengaruhi intensitas cahaya matahari, juga kebutuhan unsur hara yang diterima oleh jagung. Tidak tersedianya air dan akses cahaya matahari oleh tanaman dapat mempengaruhi terhadap banyaknya energi yang digunakan dalam fotosintesis.

Menurut Kuyik dkk. (2012), fotosintesis adalah proses dasar pada tanaman untuk menghasilkan fotosintat asimilat. Karbohidrat yang dihasilkan akan menentukan ketersediaan energi untuk pertumbuhan dan perkembangan tanaman. Cahaya merupakan faktor penting terhadap berlangsungnya fotosintesis, sementara fotosintesis merupakan proses yang menjadi kunci dapat berlangsungnya proses metabolisme yang lain di dalam tanaman.

Indeks luas daun. Berdasarkan Tabel 2, pada perlakuan $\mathrm{A}, \mathrm{B}, \mathrm{C}$, dan $\mathrm{E}$ memberikan respon yang berbeda nyata dengan Perlakuan kontrol. Pada perlakuan kontrol memiliki indeks luas daun (ILD) tertinggi jika dibandingkan dengan perlakuan lainnya, namun hasilnya kurang optimal yang disebabkan pertumbuhan tanaman yang terganggu serta tingginya bobot kering gulma. Semakin banyak dan lama suatu gulma pada areal tanaman, maka semakin besar kompetisi yang terjadi (Sembodo, 2010)

Tabel 2. Pengaruh pemberian herbisida paraquat terhadap Indeks Luas Daun.

\begin{tabular}{cc}
\hline Perlakuan & Indeks Luas Daun \\
\hline A & $2.48 \mathrm{~b}$ \\
B & $2.49 \mathrm{~b}$ \\
C & $2.44 \mathrm{~b}$ \\
D & $2.58 \mathrm{ab}$ \\
E & $2.43 \mathrm{~b}$ \\
F & $2.73 \mathrm{a}$ \\
\hline
\end{tabular}

Keterangan: nilai rata-rata yang diikuti huruf yang sama pada kolom yang sama menunjukkan tidak berbeda nyata menurut uji Duncan pada taraf $5 \%$.

Menurut Mercado (1979) yang menyatakan bahwa kompetisi terhadap cahaya matahari terjadi apabila tanaman saling memacu pertumbuhan terhadap tinggi tanaman dan tajuk tanaman, apabila tanaman utama tumbuh lebih tinggi dan rimbun maka tanaman utama akan lebih cepat menguasai cahaya matahari sehingga menaungi tanaman yang tumbuh lebih rendah. 
Hasil analisis indeks luas daun menunjukkan penggunaan dosis herbisida paraquat 414g/L dapat menggantikan persiapan lahan dengan olah tanah sempurna. Hasil perbedaan nyata tersebut membuktikan bahwa dosis herbisida sangat menentukan akvitas herbisida tersebut (King dan Oliver, 1992). Menurut Guntoro dkk (2013), bahwa perlakuan herbisida dapat memberi pengaruh secara nyata terhadap bobot kering gulma total dan menurunkan bobot kering gulma dibandingkan dengan tanpa perlakuan herbisida.

Panjang dan diameter tongkol. Berdasarkan Tabel 3, panjang tongkol dan diameter tongkol tanaman jagung pada perlakuan A, B, C, dan $\mathrm{E}$ memberikan respon yang tidak berbeda nyata dan memberikan respon yang berbeda nyata jika dibandingkan dengan perlakuan D dan F (Kontrol). Pada percobaan ini, panjang tongkol memiliki rata-rata panjang tongkol berkisar antara $16 \mathrm{~cm}$ sampai $19 \mathrm{~cm}$.

Diameter tongkol per tanaman juga memiliki rata-rata berkisar $3.5 \mathrm{~cm}$ sampai $4.2 \mathrm{~cm}$. Pada percobaan ini mayoritas pada perlakuan D dan $\mathrm{F}$ (kontrol) tongkol terbentuk sempurna. Pada sebagian perlakuan A, B, C, dan E pembentukan tongkol tersebut kurang sempurna.

Tabel 3. Pengaruh pemberian berbagai dosis herbisida terhadap panjang tongkol dan diameter tongkol per tanaman.

\begin{tabular}{ccc}
\hline Perlakuan & $\begin{array}{c}\text { Panjang } \\
\text { Tongkol } \\
(\mathrm{cm})\end{array}$ & $\begin{array}{c}\text { Diameter } \\
\text { Tongkol } \\
(\mathrm{cm})\end{array}$ \\
\hline $\mathrm{A}$ & $16.47 \mathrm{~b}$ & $3.51 \mathrm{~b}$ \\
$\mathrm{~B}$ & $16.36 \mathrm{~b}$ & $3.55 \mathrm{~b}$ \\
$\mathrm{C}$ & $16.61 \mathrm{~b}$ & $3.68 \mathrm{~b}$ \\
$\mathrm{D}$ & $18.16 \mathrm{a}$ & $4.04 \mathrm{a}$ \\
$\mathrm{E}$ & $16.19 \mathrm{~b}$ & $3.53 \mathrm{~b}$ \\
F & $19.08 \mathrm{a}$ & $4.22 \mathrm{a}$ \\
\hline
\end{tabular}

Keterangan: nilai rata-rata yang diikuti huruf yang sama pada kolom yang sama menunjukkan tidak berbeda nyata menurut uji Duncan pada taraf $5 \%$.

Pembentukan tongkol sangat dipengaruhi oleh unsur hara nitrogen. Nitrogen merupakan komponen utama dalam proses sintesis protein. Sintesis protein yang berlangsung baik akan berkolerasi positif terhadap ukaran tongkol baik panjang maupun diameter tongkol.

Pembentukan tongkol merupakan suatu tahap penting dalam hasil tanaman jagung. Pembentukan tongkol yang tidak sempurna dapat disebabkan oleh kurangnya unsur hara esensial pada tanaman jagung khususnya unsur fosfor $(\mathrm{P})$.
Pembentukan tongkol tidak sempurna dapat mengakibatkan tongkol berukuran kecil, barisan biji tidak beraturan serta biji kurang berisi. Pembentukan tongkol dapat mempengaruhi produksi jagung yang berupa biji pipilan kering.

Curah hujan yang rendah dan kompetisi antara tanaman jagung dengan gulma mempengaruhi panjang dan diameter tongkol yang dihasilkan. Kompetisi antara tanaman jagung dengan gulma serta tidak tersedianya air dapat mempengaruhi pertumbuhan dan hasil tanaman jagung tersebut.

Pengendalian gulma menggunakan herbisida dengan dosis yang kurang tepat dapat menyebabkan pertumbuhan gulma yang tinggi pada awal penanaman jagung. Keberadaan gulma pada awal pertanaman menyebabkan kerugian pada tanaman pokok berupa persaingan dalam mendapatkan air, unsur hara, cahaya matahari, dan lingkungannya (Sutoto dkk., 1996). Pertumbuhan tanaman yang kurang baik memungkinkan tanaman tidak memberikan hasil sesuai dengan potensi hasil yang dimilikinya (Leopold dan Kriedeman, 1979).

Jumlah baris biji per tongkol. Berdasarkan Tabel 4, jumlah baris biji per tongkol yang diamati menunjukan pada perlakuan A, B, C, dan $E$ memberikan respon yang tidak berbeda nyata dan memberikan respon yang berbeda nyata jika dibandingkan dengan perlakuan D dan $\mathrm{F}$ (kontrol). Hal ini menunjukan bahwa pemberian dosis herbisida pada perlakuan $\mathrm{D}$ dan dan perlakuan kontrol (F) memberikan pengaruh terhadap kualitas dan hasil tanaman jagung. Hal ini mungkin disebabkan tanaman jagung pada perlakuan $\mathrm{D}$ dan $\mathrm{F}$ lebih mampu melewati periode kritis. Pada perlakuan D dan $\mathrm{F}$, kehadiran gulma di pertanaman kurang mempengaruhi pertumbuhan generatif tanaman jagung dibandingkan perlakuan yang lainnya.

Tabel 4. Pengaruh pemberian berbagai dosis herbisida paraquat terhadap jumlah baris biji per tongkol.

\begin{tabular}{cc}
\hline Perlakuan & Jumlah baris per tongkol \\
\hline A & $12.53 \mathrm{~b}$ \\
B & $12.55 \mathrm{~b}$ \\
C & $12.68 \mathrm{~b}$ \\
D & $13.28 \mathrm{a}$ \\
E & $12.38 \mathrm{~b}$ \\
F & $13.73 \mathrm{a}$ \\
\hline
\end{tabular}

Keterangan: nilai rata-rata yang diikuti huruf yang sama pada kolom yang sama menunjukkan tidak berbeda nyata menurut uji Duncan pada taraf $5 \%$. 
Keberadaan gulma di sekitar pertanaman menyebabkan pertumbuhan jagung pada fase generatif menjadi kurang optimal dan mengakibatkan perbedaan jumlah baris biji per tongkol pada setiap perlakuan tersebut.

Bobot 100 biji. Berdasarkan Tabel 5, pada perlakuan $\mathrm{A}, \mathrm{B}, \mathrm{C}$, dan $\mathrm{E}$ memberikan respon yang tidak berbeda nyata dan memberikan respon yang berbeda nyata jika dibandingkan dengan perlakuan D dan F (kontrol). Namun dapat dilihat dari Tabel 5 bobot 100 biji tersebut masih belum maksimal. Pada deskripsi jagung menunjukkan bobot 100 biji secara umum berkisar 26,5 gram, sedangkan dalam penelitian ini bobot 100 biji berkisar 17-20 gram. Bobot 100 biji yang rendah pada penelitian ini diakibatkan oleh pembentukan tongkol yang tidak sempurna.

Tabel 5. Pengaruh pemberian berbagai dosis herbisida paraquat terhadap bobot 100 biji.

\begin{tabular}{cc}
\hline Perlakuan & Bobot $100 \mathrm{biji}(\mathrm{g})$ \\
\hline $\mathrm{A}$ & $17.13 \mathrm{~b}$ \\
$\mathrm{~B}$ & $17.30 \mathrm{~b}$ \\
$\mathrm{C}$ & $17.88 \mathrm{~b}$ \\
$\mathrm{D}$ & $19.65 \mathrm{a}$ \\
$\mathrm{E}$ & $17.18 \mathrm{~b}$ \\
F & $20.58 \mathrm{a}$ \\
\hline
\end{tabular}

Keterangan: nilai rata-rata yang diikuti huruf yang sama pada kolom yang sama menunjukkan tidak berbeda nyata menurut uji Duncan pada taraf $5 \%$.

Bobot 100 biji kering secara tidak langsung dapat mempengaruhi hasil tanaman. Bobot 100 biji merupakan parameter yang menunjukkan besar endosperm pada biji. Endosperm adalah bagian terbesar dari biji yang merupakan tempat menyimpan cadangan makanan (Kusnadi, 2000).

Komponen bobot 100 biji juga dapat dipengaruhi oleh faktor genotip dan lingkungan. Gardner dan Pearce (1991) menunjukkan bahwa menurunnya persediaan air bagi tanaman jagung pada tiga minggu setelah penyerbukan dapat mempengaruhi jumlah biji dan menurunkan bobot biji.

Bobot biji pipilan kering per tanaman dan perhektar. Berdasarkan data pada Tabel 6 pada perlakuan A, B, C, dan E memberikan respon yang tidak berbeda nyata dan memberikan respon yang berbeda nyata jika dibandingkan dengan perlakuan $\mathrm{D}$ dan $\mathrm{F}$ (kontro) terhadap bobot biji pipilan kering per tanaman maupun per hektar. Keberadaan gulma dapat menyebabkan tanaman mengalami defisiensi unsur hara, sehingga pertumbuhan dan perkembangan tanaman menjadi terganggu. Akibatnya ukuran biji menjadi lebih kecil yang berakibat pada penurunan bobot 100 biji dan bobot biji pipilan kering per tanaman maupun per hektar.

Tabel 6. Pengaruh pemberian berbagai dosis herbisida paraquat terhadap bobot biji pipilan kering per tanaman (g) dan bobot biji pipilan kering per hektar (ton).

\begin{tabular}{ccc}
\hline Perlakuan & $\begin{array}{c}\text { Bobot biji pipilan } \\
\text { kering per } \\
\text { tanaman }(\mathrm{g})\end{array}$ & $\begin{array}{c}\text { Bobot biji } \\
\text { pipilan kering } \\
\text { per hektar (ton) }\end{array}$ \\
\hline $\mathrm{A}$ & $59.75 \mathrm{~b}$ & $3.42 \mathrm{~b}$ \\
$\mathrm{~B}$ & $60.75 \mathrm{~b}$ & $3.46 \mathrm{~b}$ \\
$\mathrm{C}$ & $61.25 \mathrm{~b}$ & $3.50 \mathrm{~b}$ \\
$\mathrm{D}$ & $78.25 \mathrm{a}$ & $4.46 \mathrm{a}$ \\
$\mathrm{E}$ & $55.5 \mathrm{~b}$ & $3.18 \mathrm{~b}$ \\
$\mathrm{~F}$ & $85.75 \mathrm{a}$ & $4.90 \mathrm{a}$ \\
\hline
\end{tabular}

Keterangan: nilai rata-rata yang diikuti huruf yang sama pada kolom yang sama menunjukkan tidak berbeda nyata menurut uji Duncan pada taraf $5 \%$.

Rata-rata hasil produksi jagung hibrida Bisi-2 menurut deskripsi adalah 8,9 t/ha pipilan kering, sedangkan menurut hasil penelitian ini didapatkan rata-rata tertinggi pipilan kering sebesar 3 hingga 5 ton/ha. Hasil pipilan kering yang rendah pada penelitian ini berkaitan dengan rendahnya bobot 100 biji.

Keberedaan gulma dengan populasi yang tinggi dapat menekan pertumbuhan jagung sehingga terganggunya hubungan source dan sink pada tanaman. Aktivitas source diperlukan selama pertumbuhan vegetatif tanaman sedangkan aktivitas sink diperlukan pada fase pengisian biji. Tidak tersedianya air dan unsur hara yang cukup menyebabkan proses fotosintesis dan translokasi asimilat terganggu, sehingga mengakibatkan penurunan hasil fotosintat yang terakumulasi pada batang, daun, tongkol, dan biji (Jumin, 1989).

\section{Kesimpulan}

Berdasarkan hasil dan pembahasan, maka kesimpulan dari percobaan ini adalah : Pemberian herbisida paraquat untuk persiapan lahan tanpa olah tanah (TOT) pada tanaman jagung mampu menggantikan olah tanah sempurna (OTS). Perlakuan dengan dosis herbisida tertinggi yaitu $414 \mathrm{~g} / \mathrm{L}$ dapat menggantikan persiapan lahan dengan OTS. 


\section{Daftar Pustaka}

Badan Pusat Statistik. 2015. Produksi Jagung Indonesia.

https://www.bps.go.id/linkTableDinami s/view/id/868

Gardner, F.P., R.B. Pearce dan R.L. Mitchell., 1991. Fisiologi Tanaman. Gadjah Mada Universty Press. Yogyakarta.

Gratio, Fridolin dan Sukamto, Andreas. 2013. Pendapatan dan Fungsi Produksi Jagung. Universitas Atma Jaya Yogyakarta.

Guntoro, D., K. Agustina dan Yursida. 2013. Efikasi herbisida penoksulam pada budidaya padi sawah pasang surut untuk intensifikasi lahan suboptimal. Jurnal Lahan Suboptimal 2(2). 144-150.

Harjadi, S. S. 1993. Pengantar Agronomi. Gramedia. Jakarta.

Jumin, H.B., 1989. Ekologi Tanaman : Suatu Pendekatan Fisiologis. Rajawali Pers. Jakarta.

King, C. A., dan L. R. Oliver. 1992. Application Time and Timing of Acciflouren, Bentazon, Chlorimuron and Imazaquin. Weed Technology. 6 (3) : $526-534$.

Kusnadi, M.H. 2000. Kamus Istilah Pertanian. Kanisius. Yogyakarta

Kuyik, A.R., T. Pemmy., D.M.F.Sumampow., dan E.G. Tulungen. 2012. Respons Tanaman Jagung Manis (Zea mays sacharata L.) Terhadap Pemberian Pupuk Organik. Faperta Univ. Sam Ratulangi. Manado.
Leopold, A.C., and P.E. Kriedeman, 1979. Plant growth and development. Mc Graw Hill Book Company Inc. New Delhi.

Mercado, B.L. 1979. Introduction to Weed Science. Searca. Philippines. Pp.291

Moenandir, J. 2010. Ilmu Gulma. Universitas Brawijaya Press. Malang.

Perkasa, Achmad Yozar. 2015. Studi Pengendalian Gulma dengan Menggunakan Herbisida pada Budidaya Kedelai Jenuh Air di Lahan Pasang Surut. Sekolah Pascasarjana Institut Pertanian Bogor.

Purwono dan R. Hartono. 2005. Bertanam Jagung Unggul. Penebar Swadaya, Jakarta.

Rina, Y., R.S. Simatupang. 1998. Analisis usaha tani kedelai pada sistem olah tanah konservasi di lahan rawa lebak kalimantan selatan. Dalam: Z. Irfan, Z. Lamid, D. Jahja, Irawati \& Ardi (eds.). Prosiding Seminar Nasional VI Budidaya Olah Tanah Konservasi. Padang.

Sembodo, D. R. J. 2010. Gulma dan Pengelolaannya. Graha ilmu. Yogyakarta.

Sutoto, S.R., R. Soedharoedjian., A.T. Soejono. 1996. Alternatif penentuan periode kritis jagung manis terhadap kompetisi gulma. Pros. Konf. HIGI XIII. 7 - 13

Syam'um, E. 2002. Hasil dua kultivar kedelai (Glycine max (L) Merr) pada musim dan sistem olah tanah berbeda. Jurnal Agrivigor. 2 (1):32-37.

Tjitrosoedirdjo, S., I. H. Utomo, dan J. Wiroatmodjo (eds.). 1984. Pengelolaan Gulma di Perkebunan. Gramedia. Jakarta 